ISMC 2021

$16^{\text {th }}$ International Strategic Management Conference

\title{
THE IMPORTANCE OF WOMEN AMONG POLISH SCIENTISTS IN THE FIELD OF LOGISTICS
}

\author{
Sylwia Konecka (a)* \\ *Corresponding author \\ (a) Poznan University of Economics and Business, al. Niepodleglosci 10, Poznan, Poland, \\ Sylwia.Konecka@ue.poznan.pl
}

\begin{abstract}
The article presents the results of own research aimed at estimating the contribution of female scientists to the development of logistics in Poland. The problem was set against the background of gender differences in overall employment and the existing inequalities in the overall employment of women in Poland compared to other countries, as well as the employment of women in education and the logistics industry. A quantitative approach was used to examine the structures of selected state universities in terms of the number of women employed. An analysis of the Polish state universities that included in the group of universities, technical universities, universities of economics and universities of natural sciences that are listed by Ministry of Higher Education and Science was carried out in order to determine the structure of women's employment - their total number among all employees, distribution regarding degrees and academic titles, as well as the positions held. Taking into account the contribution of women to the development of logistics, it is necessary to point out the phenomenon of a "leaky pipeline" found in general in the world of science as well as in relation to others disciplines and countries. This phenomenon means that among the professors specializing in logistics in Poland, for every 30 males, there are five female academics.
\end{abstract}

2357-1330 C 2021 Published by European Publisher.

Keywords: Gender equality, logistics, Polish scientists, transport, women 


\section{Introduction}

The professional activity of all women in Poland is low compared to other European Union (EU) countries. Few over $63 \%$ of women in the working age (15-64) are economically active, compared to an average of $68 \%$ in UE28 (Magda, 2020).

According to Organization for Economic Co-operation and Development (OECD, 2012):

Young women in Poland are more likely to have a university degree than young men: 43\% of women and 29\% of men aged 25-34 years old have attained tertiary education. About $75 \%$ of university graduates of courses in health and welfare-related studies were women, compared with only $34 \%$ women in engineering and $16 \%$ in computing. As a result, women make up $81 \%$ of workers in health and social services and $71 \%$ of teachers. By contrast, only $30 \%$ of workers in the transport, storage and communication sectors are women. (...) At 59\%, the proportion of employed women in Poland is around the OECD average 60\%. (p. 1)

OECD International Survey of Scientific Authors (ISSA2, 2021) shows that:

Women are under-represented in research careers (...). On average across OECD countries, women comprise only around 40 percent of all researchers and they are considerably less likely to be in leadership positions. Only 30 percent of corresponding authors are women. (...) The magnitude of this gender gap varies significantly across fields of research. In the social sciences and psychology, 45 percent of corresponding authors are women, while women account for only 15 percent of corresponding authors in physics and astronomy.

Transport and logistics have traditionally been male-dominated (Gartner, 2021). Women constitute less than $10 \%$ of the employees in managerial positions in transportation and logistics. On average, female holders of the Master Business Administration (MBA) degree were paid $\$ 4600$ less in their first job than their male counterparts, despite their prior experience, time since MBA, job level, region, industry and even parenthood were taken into account. The number of women to achieve professional certificates, for example the European Logistics Association (ELA) Certificate, is also lower than this of male candidates. In 2017, the proportion between women and men who obtained such certification was $28 \%$ to $72 \%$. This difference also persisted in 2021 ; by November $2021,37 \%$ of women and $63 \%$ of men obtained the ELA certificate (Lobacz, 2021). Although studies on equality and women (e.g., in the UK and the US) have been done since the early 1980s, the issue of female employment in transport and logistics is a relatively new topic. The European regulations considered women and transport issues at the beginning of this century, and the relevant EU-funded research projects began less than 20 years ago (Ortega Hortelano et al., 2019).

One may consider the attendees at the Council of Supply Chain Management Professionals Annual Global Conference. At the turn of the 1970s and 1980s, the percentage of women participating in the conference was $2 \%$. It grew to around $8-10 \%$ in the 1990 s, and is now around 15\% (Cooper et al., 2016; Zinn et al., 2018). The number of women in university courses in logistics and supply chain management amounts to around 50\% (Kaplan, 2018). 
According to the European Commission Report (Ortega Hortelano et al., 2019), in the European transport sector, women are underrepresented compared to their male counterparts (22\% of workers are female). An analysis of the 769 transport researchers working in 21 European projects (selected from the TRIMIS database) and 223 organisations, revealed that approximately $22 \%$ of the researchers are females. Women are also underrepresented in the jobs linked to transport science and engineering and the same can therefore be assumed regarding transport research.

The analysis conducted by Ruel and Jaegler (2021, as cited in Ma et al., 2020) shows that:

There were $33.5 \%$ women recruited in the MSc.; gender significantly influences the number of years spent at each level in the career hierarchy; gender has a far greater influence on career progression than the expatriation choice (however women are more collaborative than men in the role of both buying agents and supply agents); the information about counterparts' gender affects behaviours, as both genders are more collaborative when paired with women than when paired with men; all-women supply chain pairs outperform all other gender pairings in supply chain efficiency. (p. 6907)

Esper et al. (2020) call for more research on gender diversity in logistics. Therefore, the author undertook research in the field of the situation of women scientists working in the field of logistics in Poland.

\section{Research Method and Characteristics of the Research Sample}

Own research was preceded by a review of Polish and international literature in English. The available studies concerned the economic activity of women in Poland (Magda, 2020), the analysis of the employment gap and wages of women and men (PARP, 2020), differences in the amount of retirement benefits (Duda, 2020) and unemployment (Central Statistics Office, 2020). However, there were no scientific studies on the situation of women in the area of transport and forwarding and scientific activities taken together.

In June 2021, an analysis of Polish State Universities, the including universities of technology, economics, natural sciences was carried out in order to determine the structure of female employment, i.e. their percentage with respect to all employees, the distribution of degrees and academic titles, as well as the positions held. Out of 18 universities that were analyzed, eight universities contain the term "logistics" in their name. Another group to be studied included 18 universities of technology, of which 10 universities were finally subjected to further analysis because in the organizational structure they had faculties and/or institutes, chairs, or departments of logistics. The study included also five universities of economics as in each of them there are teams of scientists dealing with logistics. There are also six universities of agriculture and natural science and three of them have units carrying out didactic and research tasks related to logistics. There are five universities of pedagogy and six universities of physical education, as well as one educating theologists. This study did not include these universities as they do not carry out any research in the field of logistics.

There were several other universities included in this study even though they are not supervised by the Ministry of Higher Education and Science. The reason was that they carry out interdisciplinary 
research activities into logistics. These included Military University of Technology, Aviation Military Academy, Maritime University of Szczecin and Maritime University of Gdynia.

In addition, all 32 state vocational colleges were studied, of which only three have separate organizational units dealing with logistics in their structures. In the case of these vocational schools, however, it was not possible to identify by name and title the employees carrying out the teaching process.

Private universities were also taken into account, as they also educate a lot of logisticians, however it turned out that the data on employees were not available and even if they were, their academic staff were often the same researchers employed by state universities who happened to hold additional teaching jobs in private universities. Therefore, the entities that are not state universities, although subject to the Ministry of Higher Education and Science, were not analysed.

In the end, the research sample consisted of 544 employees of 34 public universities employed in organizational units dealing with broadly understood logistics. The method of selecting the sample seems to be the most accurate, although of course, it has some shortcomings, even if it does not take into account numerous non-public universities. Examining each individual university was, of course, timeconsuming, but the databases previously held enabled the data collection process to be carried out fairly efficiently.

\section{Findings from Analysis of Organizational Structures of Public Universities in Terms of Employment of Women Logisticians}

The analysis of the collected data on the academic staff employed in departments, chairs, colleges, institutes of logistics first concerned the number of women in relation to the total number of employees. The following Universities of Technology with the most numerous teams dealing with logistics include such locations as Silesia -56 , Bialystok -32 and Poznan -29 . There are four more universities with over 20 employees in logistics, i.e., the University and Technical University of Lodz, the Wroclaw University of Economics and the Czestochowa University of Technology. Initially, it was assumed that there would be disproportions in the number of employees of different sexes, especially at military technical universities. It turned out, however, that significant disproportions in the general distribution of male and female employees occur only in the Military University of Technology - all six employees are male and the Aviation Military Academy where 16 out of 19 employees are male. However, at the Maritime University of Szczecin and the Maritime University of Gdynia, more women than men work in logistics departments, respectively $10 \mathrm{~F} / 6 \mathrm{M}$ and $6 \mathrm{~F} / 5 \mathrm{M}$. On the other hand, in as many as seven out of ten analyzed technical universities, their logistics teams are dominated by women. These disproportions are not large, with a maximum of three more women than men working in the analysed units. However, if men outnumber women, the number is strikingly high. For example, at the Rzeszów University of Technology in the Department of Management and Logistics Systems, there are only two women in the team of 14 academics. There is a similar disproportion at the Warsaw University of Technology; the Department of Transport Systems Engineering and Logistics employs 2 women and 11 men. In the most numerous Department of Management and Logistics at the Silesian University of Technology, one could say that there is almost a parity - 26 women and 30 men. However, only the University of Łódź and the Nicolaus 
Copernicus University in Torun can boast of actual parity. When analysing the proportions of women to men at the Universities of Economics, it should be noted that at two of them women prevail - in Wrockaw and Poznań, while at the other three men prevail.

However, at all three vocational colleges men outnumber women. At the Wielton State Vocational College in Legnica there are only 6 women to 14 men, at the State Vocational College in Ciechanów there are 4 women to 8 men, and at the State Vocational College in Nowy Sącz only one woman and 9 men work at the Department of Logistics and Transport.

Overall, among all 544 identified employees, 245 are women and 299 are men.

There were no significant differences in the basic number of women employed in the departments of logistics, which is why an analysis of the number of women with different academic degrees was undertaken (professional and/or academic title). The detailed data on the total number, the number of women and the number of men holding a specific professional, military or scientific title or rank are presented in table 1 .

Table 1. Total number of women and men logisticians by degrees, academic, professional and military titles (as at 30.06.2021)

\begin{tabular}{cccc}
\hline $\begin{array}{c}\text { Degree/professional/scientific/military } \\
\text { degree }\end{array}$ & Number of women & Number of men & Total number \\
\hline MA/MSc & 58 & 58 & 116 \\
PhD/PhD Eng. & 140 & 126 & 266 \\
dr hab.*/ dr hab. Eng. & 17 & 36 & 53 \\
dr hab./dr hab. Eng., university prof. & 28 & 34 & 62 \\
prof. dr hab./prof. dr hab. inż. & 5 & 30 & 35 \\
PhD, university prof. & 0 & 2 & 2 \\
prof. dr hab. Eng., doctor h.c.** & 0 & 2 & 2 \\
dr hab., university prof., doctor h.c. & 1 & 0 & 1 \\
prof. visit. dr. oec. HSG & 0 & 1 & 1 \\
captain MSc & 1 & 0 & 1 \\
lieutenant colonel MA & 0 & 1 & 1 \\
lieutenant colonel PhD Eng. & 0 & 1 & 2 \\
colonel PhD/colonel PhD Eng. & 0 & 2 & 1 \\
no data & 1 & 0 & 544 \\
\hline Overall & 251 & 293 & \\
\hline
\end{tabular}

\footnotetext{
* Post-doctoral degree (habilitated doctor)

** doctor honoris causa
}

There is no difference in the number of men and women with a master's degree, the logisticians holding a doctoral degree are slightly more numerous among women, while this proportion changes with the development of their scientific career. There are more male logisticians with a post-doctoral degree, including university professors in general; there are 70 male logisticians with a post-doctoral degree, while only 45 female logisticians. At the highest level of the academic career, there are only 5 female logisticians with a professorial degree. Having a professorial title is not so rare among men, with as many as 30 male professors. On the basis of the data presented in table 2, the question arises as to the possible reasons for this state of affairs. Does it mean that women are less intellectually capable? Or perhaps social conditions, which often unequally place more responsibilities on women in relation to raising children 
and maintaining the home? It is also possible that men are better able to use their skills, are goal-oriented and assign the highest priority to their professional career which is why they are more likely to give up other areas, e.g. not starting a family or giving up sports, hobbies and passions. Obviously, this chapter will not provide answers to these questions, as they would have to be the subject of much broader research in the field of social sciences rather than logisticians. This type of research, concerning scientific careers of women (not only logisticians) placed in the context of family life, also covering the system of support from the state and universities in terms of combining professional and parental roles, was for example conducted by Ewa Krause PhD from the Department of Labour Pedagogy and Andragogy, Faculty of Pedagogy, UKW in Bydgoszcz. The author of this chapter had the pleasure to be their respondent. The results, as yet, remain to be seen. However, her previous research confirms that the trend observed among female logisticians is present across the scientific community. The higher the level of the scientific career, the fewer women there are. Although more and more females are obtaining doctoral degrees, there are far fewer of them obtaining habilitation and professorships. Few of them also reach the highest positions in the professional hierarchy (Krause, 2019). Why this happens, and what is the phenomenon of the "disappearance", "leakage" or " dropping out" of women scientists, called in the literature the "leaky pipeline", the term described in the article Women's scientific careers (Krause, 2019). The author of the study argues that the wasting of the potential of women scientists is particularly noticeable precisely in the sphere of science and higher education. Motherhood is the most important factor causing women to leave science career or slowing down its pace. The results of Lawson et al. (2021) study, which according to the researchers are universal to all fields of science and to most countries, indicated that female researchers with young children received less funding to conduct their own research and also achieved lower citation rates than their male and childless colleagues in similar positions. Business travel or scientific internships, which are an important part of scientific development, are a major problem for mothers who attempt to pursue academic career.

The predominance of men at successive stages of academic career is particularly evident when comparing the data on the number of women, who in Poland invariably constitute the majority of students - approximately $60 \%$. In the world of science, on the other hand, this proportion is reversed - they constitute between 25 and $45 \%$ of all researchers in most (54 out of 90) countries in the world. Poland therefore has a relatively high proportion of women in science and higher education. However, the feminisation of this sector occurs in those countries where the level of science is not high and it is underfunded, and where research budgets are the lowest (Młodożeniec \& Knapińska, 2013).

The analysis of logistics academics was also broken down into those with the professional title of engineer (B.Eng.) turns out that in the total number of male engineers definitely prevail, for 105 women there are 152 men (see Table 3). Thus, the number of female engineers accounts for $2 / 3$ of the number of male engineers. The result of this analysis is disproportionate to the result of the analysis concerning women and men employed in particular organisational units of technical universities (according to Table 1). It turns out that this is due to the fact that female and male employees of logistics departments at technical universities are not necessarily engineers. At the Silesian University of Technology out of 56 employees of the Department of Management and Logistics 14 do not have the title of engineer, at the Białystok University of Technology out of 32 as many as 17 employees of the International Department 
of Logistics and Service Engineering are not engineers, similarly at the Częstochowa University of Technology out of 21 employees of the Department of Logistics and International Management there are only 10 engineers. This is not a rule, because for example at Poznan University of Technology, only three out of 29 employees of the Chair of Production Management and Logistics are not engineers, and at the Technical University of Lodz only four out of 24 are not engineers. However, it makes the general disproportion between women and men logisticians who hold the B.Eng. degree visible only when their total number is considered (nationwide), not when the proportions studied in individual universities and their organisational units are analyzed.

Table 2. Number of non-engineer logisticians broken down by men and women

\begin{tabular}{cccc}
\hline Degree / professional / scientific & Female & Male & Total \\
\hline MA & 38 & 34 & 72 \\
PhD & 80 & 61 & 141 \\
PhD, university prof. & 0 & 2 & 2 \\
dr hab. & 8 & 9 & 17 \\
dr hab., university prof. & 15 & 18 & 33 \\
dr hab., university prof., doctor h.c. & 1 & 0 & 1 \\
prof. visit. dr. oec. HSG & 0 & 1 & 1 \\
prof. dr hab. & 3 & 14 & 17 \\
Other & 1 & 2 & 1 \\
Overall & 146 & 141 & 285 \\
\hline
\end{tabular}

The disproportion between the number of women and men as in the case of logistics engineers was not observed in the case of those without an engineering degree. As shown in Table 2, the number of men and women is similar, with 5 men outnumbering women $(141 \mathrm{M} / 146 \mathrm{~F})$. However, as in the case of engineering logisticians, we are dealing with the phenomenon of a "hole in the pipeline". While the number of male and female holding the M.Eng. degree is comparable, and the number of women with a $\mathrm{PhD}$ degree is higher - 80 to $61 \mathrm{men}$, at the habilitation stage the proportions reverse, albeit slightly. There is a significant advantage of 15 female titular professors over three female professors.

Table 3. Number of logisticians with the professional title of engineer broken down by women and men

\begin{tabular}{cccc}
\hline Degree / professional / scientific & Female & Male & Total \\
\hline MSc & 20 & 24 & 44 \\
PhD Eng. & 60 & 65 & 125 \\
dr hab. Eng. & 9 & 27 & 36 \\
dr hab. Eng., university prof. & 13 & 16 & 29 \\
prof. dr hab. Eng. & 2 & 16 & 18 \\
prof. dr hab. Eng., doctor h.c. & 0 & 2 & 2 \\
other & 1 & 2 & 1 \\
Overall & 105 & 152 & 255 \\
\hline
\end{tabular}

The demonstrated relationships in gender differentiation may become the basis for further research. The quoted research on careers of women scientists in all fields and disciplines shows that e.g. a detailed analysis of careers of employees of one University (the research sample consisted of 262 persons), can be used to analyse the careers of logisticians who are PhDs and professors of logistics. It 
could be determined whether the situation described in the Kraus study occurs here as well, that women more often than men engage in teaching, which is perceived in the academic environment as a less significant activity than, for example, conducting research.

Much more often than men in similar positions, women are assigned the time-consuming administrative activities that distract them from their main research path. They have to prove themselves more to be evaluated at the same level as men, e.g. research shows that a woman, in order to get the same position, must have more publications.

There is also the possibility that the above concern staff who are professors, which is associated with a certain age and the current balance in the number of women and men who are masters and doctors will be preserved in the future, with the development of the careers of current female doctors. The ongoing social changes are changing the way we perceive the role of women in society. The new generation of women starting their studies and scientific careers is not guided by the schemes and stereotypes of their mothers and grandmothers. And above all, they feel equal to men in the potential to develop a professional or scientific career.

\section{Conclusion}

Policies should increase the awareness of equality and respect among men and women as in doing so they address gender equality. Several reasons explain the underrepresentation of women (e.g. difficulty to find a work-life balance in shift work, lack of appropriate working environment and equipment, etc.) and this requires a diverse policy response. Greater understanding of the reasons behind the lack of female transport researchers is needed to increase the share of women in transport (Ortega Hortelano et al., 2019).

Also, Gartner in 2021 saw a significant leap in the percentage of supply chain organizations that articulate and document gender DEI (equity and inclusion) goals. The proportion of supply chain organizations with stated goals increased from $64 \%$ in 2020 to $73 \%$ in 2021 . Maurelli and Mussome (2020) state that the supply chain industry is currently undergoing a significant skills shortage, which is exacerbated by rapidly evolving roles that are becoming increasingly harder to fulfil. Actively recruiting more female candidates may enable companies to cast a wider net and may be a compelling approach to addressing the skills shortage and driving supply chains forward.

In conclusion, it should be stated that logistics is popular both in technical, natural, military and professional universities and is usually attributed to the discipline of management and quality science. It has also seen specific cognitive schemes and theories that have already passed the testing stage for explaining phenomena related to logistics. Taking into account the contribution of women to the development of logistics, it is necessary to point out the phenomenon of a "leaky pipeline" found in general in the world of science as well as in relation to others disciplines and countries. This phenomenon means that among the professors specializing in logistics, for every 30 males, there are five female academics. The situation is not better if the publication achievements are concerned. Of course, this analysis involves only a selected area, characterized by a high level of scientific science, and logistics as a field of practical knowledge is studied by both men and women. The presented results of quantitative research on the number of departments, institutes, faculties or logistics departments at Polish universities 
in the selected scope are exhaustive, but could in the future still include non-public universities. On the other hand, the quality analysis of the previous publication achievements may be treated as a kind of research reconnaissance, as it would require a generalization and both in the subject area, for the most part, it would be worth exploring beyond the keyword "logistics", the keyword "supply chain, "supply network", expand the database.

\section{References}

Central Statistics Office. (2021). Higher education in the academic year 2020_2021 (preliminary results). Retrieved June 15, 2021, from https://stat.gov.pl/obszary-tematyczne/edukacja/edukacja/ szkolnictwo-wyzsze-w-roku-akademickim-20202021-wyniki-wstepne,8,7.html

Cooper, M. C., Esper, T., Stolze, H., Kent, J., \& Ma, S. (2016). Career Patterns of Women in Logistics: How Are Companies Managing Omni-Channel and Consumer-Driven Supply Chains? Paper presented at the Council of Supply Chain Management Professionals Annual Conference, September 25-28, Orlando, FL.

Duda, K. (2020). Sytuacja kobiet na rynku pracy w Polsce [The situation of women in the labor market in Poland]. https://oppz.org.pl

Esper, T. L., Goldsby, T. J., \& Zinn, W. A. (2020). Challenge in Our Time: Issues of Race in Supply Chain Management. Journal of Business Logistics, 41, 178-181. https://doi.org/10.1111/jbl.12257

Gartner (2021). Women in Supply Chain Survey Shows Resilience, Improvement in Representation. An excerpt from the Gartner. AWESOME Women in Supply Chain Survey.

Kaplan, D.A. (2018). How Universities Are Grooming Talent for the Future Supply Chain. Supply Chain Dive. Retrieved 15 June, 2021 from https:// www.supplychaindive.com/news/universitiesgrooming-talentfuture-supply-chain-diversity/519455

Krause, K. (2019). Kariera naukowa kobiet [Scientific career of women]. Edukacja Ustawiczna Dorostych, 1, 104.

Lawson, C., Geuna, A., \& Finardi, U. (2021). The funding-productivity-gender nexus in science, a multistage analysis, Research Policy, 50(3). https://doi.org/10.1016/j.respol.2020.104182

Lobacz, K. (2021). Advancing Women in Transport and Logistics. presentation from ELA Awards 2021 Retrieved 9 November, 2021.

Ma, S., Hao, L., \& Aloysius, J. A. (2020). Women are an advantage in supply chain, Production and Operations Management, 30(5), 1427-1441. https://doi.org/10.1111/poms.13329

Magda, I. (2020). Jak zwiększyć aktywność zawodowa kobiet w Polsce? [How to increase the professional activity of women in Poland?] Instytut Badań Strukturalnych.

Maurelli, M., \& Mussome, A. (2020). Inclusion as the competitive advantage. The case for women in supply chain. Deloitte Development LLC.

Młodożeniec, M., \& Knapińska A. (2013). Does science still have a male gender? Women's participation in science, Science, 2.

OECD. (2012). Closing the Gender Gap: Act Now. Poland Final. OECD Publishing. Retrieved 14 June, 2021, from https://doi.org/10.1787/9789264179370-en

OECD. (2021). International Survey of Science (ISSA2). OECD Publishing. Retrieved 15 June, 2021, from https://www.oecd.org/gender/data/it-is-time-to-close-the-gender-gap-in-research.htm

Ortega Hortelano, A., Grosso, M., Haq, G., Tsakalidis, A., Gkoumas, K., van Balen, M., \& Pekár, F. (2019). Women in European transport with a focus on Research and Innovation. An overview of women's issues in transport based on the Transport Research and Innovation Monitoring and Information System (TRIMIS), European Commision. European Union.

PARP. (2020). Analiza luki zatrudnienia oraz wynagrodzen kobiet $i$ mężczyzn [Analysis of the employment and wage gap between women and men]. Instytut Analiz Rynku Pracy, Warszawa.

Ruel, S., \& Jaegler, A. (2021). Impact of Gender and Expatriation Choice on Career Paths in Supply Chain Management. Sustainability, 13, 6907. https://doi.org/10.3390/su13126907

Zinn, W., Goldsby, T. J., \& Cooper, M. C. (2018). Researching the Opportunities and Challenges for Women in Supply Chain. Journal of Business Logistics, 39(2), 84-86. https://doi.org/10.1111/jbl.12186 